\title{
Preparing an ICT Innovation using Lectora Inspire as Teaching Media for Buffer Solutions for High School
}

\author{
Erika Siska Yolanda Siagian \\ Postgraduate Program of Chemistry Education \\ State University of Medan \\ Medan, Indonesia \\ Widya Irfani \\ Postgraduate Program of Chemistry Education \\ State University of Medan \\ Medan, Indonesia
}

\author{
Ramlan Silaban* \\ Department of Chemistry Education \\ State University of Medan \\ Medan, Indonesia \\ drrsilabanmsi@yahoo.co.id \\ Mahmud \\ Department of Chemistry Education \\ State University of Medan \\ Medan, Indonesia
}

\begin{abstract}
This study aims to obtained ICT based Lectora Inspire media as learning media for buffer solution in high school class XI and to determine the feasibility of ICT based Lectora Inspire media according to national education standards board. This study uses research development method with Borg \& Gall modified model. The feasibility of media was assessed descriptively based on assessment score from expert validators consist of lectures and chemistry teachers. The results show that, ICT based lectora inspire learning media has been obtained as learning media for buffer solution in high school class XI. The approval results from expert validator shows content feasibility score 3.83 , language feasibility 3.77 , and presentation feasibility 3.73, thus ICT based lectora inspire learning media is feasible to be used as learning media in accordance with national education standards board.
\end{abstract}

\section{Keywords: Buffer Solution, ICT, lectora inspire}

\section{INTRODUCTION}

In the technological era, the use of computers have added all fields of life, including in education. Computers have practical application programs that could be used and developed to obtain educational goals. Innovations in education could be done by using learning [1]. Some orientation use of computers in education was to help people to learn, teach, and help people manage general education [2]. The use of computer in learning has several advantages, includes: (1) it could make learning more meaningful, because by involving the senses of sight, hearing, and feeling students can obtain information and knowledge directly; (2) students could adjust the level of learning speed with their ability level; (3) practical, could clarify the subject matter, overcome the limitations of space, time, energy, and senses; (4) make the learning process more interesting, interactive and allows students to learn independently; (5) it could stimulate students to learn because of the availability of animated graphics, colors, and music that could add to realism. The use of computers could create a more pleasant learning atmosphere [3]. Display animated images and regularity of messages and symbols which could motivate student curiosity [4]. The use of multimedia in teaching materials becomes interesting, because it could integrate various learning media so that it could motivate students to learn independently [5].

Applications used in making interactive multimedia were Macromedia Flash, Powerpoint, and Chemsketch which have made easy to decipher concepts and examples in chemistry learning [6]. Utilization of technology was very necessary for the delivery of material, especially those, that were interactive multimedia. The development of lectora inspire as a learning media is one solution to overcome these problems. Lectora inspire was an effective program in making learning media. Lectora inspire was an electronic learning development software (e-learning) that was relatively easy to apply or apply because it does not require an understanding of sophisticated programming languages. Because lectora inspire has an interface that was familiar to those of us who already know and master Microsoft Office [7].

The development of technology is very influential on learning innovation [8]. The contribution of instructional media in conveying learning messages is more standardized, more attractive, more interactive, learning time can be shortened, the quality of learning can be improved, the learning process can take place indefinitely, students behave and lecturers play a positive role towards learning [9]. One of the chemistries learning material in high school is buffer solution. The buffer solution is one of the chemicals concepts that were considered difficult and complex, because besides contains the theory also includes calculations. The concept of buffer solution is quite a lot of applications and very common in all around us, but still lacking to be conveyed to students. The buffer solution in daily life has a very important role. For example in the pharmaceutical industry, a buffer solutions plays a role in the manufacture of medicine such as eye drops, injectable drugs so that the active substance of the drug has a specific $\mathrm{pH}$ and was adjusted to the body's $\mathrm{pH}$. In living bodies, the buffer solution plays a role in maintaining the $\mathrm{pH}$ of intracellular fluid and fluid outside the cell (blood), if there 
was even a slight change of $\mathrm{pH}$ in the blood it could be dangerous or even death. Many studies have been conducted to explain multimedia based learning. Research conducted on the development of instructional media using interactive multimedia Lectora Inspire in Basic Electronics Engineering subjects at SMK Negeri 3 Jombang was very well categorized to be used in learning with a percentage of $84 \%$ and getting very interesting responses from students with a percentage of $86.19 \%$ [10]. In addition, research was conducted on acid-base material in which content feasibility (4.8) and presentation feasibility (4.7) of a maximum score of 5.0 [11].

Based on the description above, the purpose of this research development is to (1) obtain ICT based lectora inspire media as a learning media Buffer Solution in class XI senior high school (2) find out the feasibility of ICT based lectora inspire media according to national education standards board.

\section{METHOD}

The types of study were Research and Development. The development model used was the modified Borg and Gall. The stages of development research includes; the needs analysis, media development and media assessment. The expert validators in this study were 3 validators namely material experts, educators and media experts.

Data collection techniques used in this study was a to national education standards board questionnaire that had been modified in accordance with the needs of the learning media that had been developed. The data generated was descriptive in nature, namely media assessments obtained from the results of the analysis of material experts and media experts on products developed based on a questionnaire with a likert scale 1-4.

\section{RESULT}

\section{A. Media Development}

The table below shows all components and their corresponding features of the media learning.

\begin{tabular}{clcc} 
& \multicolumn{2}{c}{ TABLE 1. RESULT OF MEDIA DEVELOPMENT } \\
\cline { 3 - 4 } No & \multicolumn{2}{|}{ Development Menu } & Interactive Learning Media \\
\cline { 3 - 4 } & & Before & After \\
\hline 1 & Instruction menu & No & Yes \\
\hline 2 & Competency Menu & No & Yes \\
\hline 3 & Material Menu & No & Yes \\
\hline 4 & Games Menu & No & Yes \\
\hline 5 & Evaluation Menu & No & Yes \\
\hline 6 & Profil Menu & No & Yes \\
\hline 7 & Videos on Media & No & Yes \\
\hline 8 & Pictures on Media & No & Yes \\
\hline 9 & Animations on Media & & \\
\hline
\end{tabular}

\section{B. Media Assesment}

ICT based lectora inspire media assessment on buffer solution by expert validators on the aspects of content feasibility, language feasibility and presentation feasibility, overall presentation feasibility of 3.77 in the valid category and can be used in the chemical learning process on buffer solution. Overall media assessment could be seen in Fig. 1

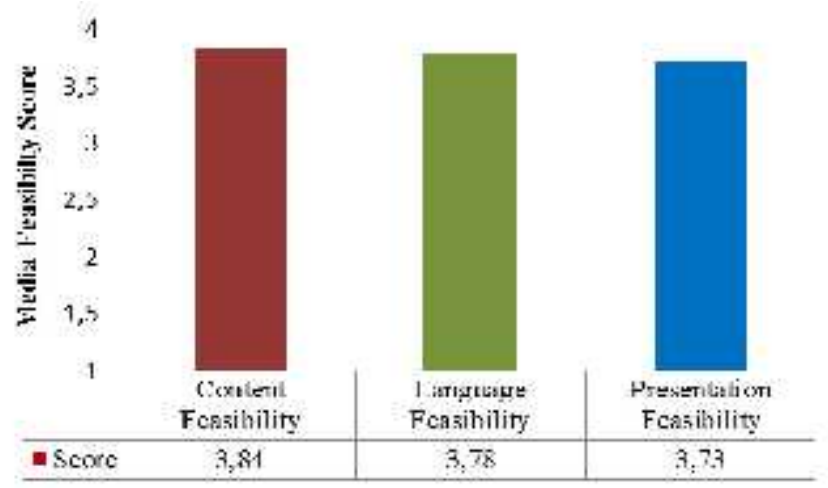

Fig. 1. Validation Results for Learning Media Feasibility

1. Content Feasibility

ICT based lectora inspire media assessment on buffer solution by expert validators on the content feasibility aspect was 3.84 in the valid category and could be used in the chemistry learning process in the buffer solution. Media assessment on the content feasibility aspect could be seen in Fig. 2.

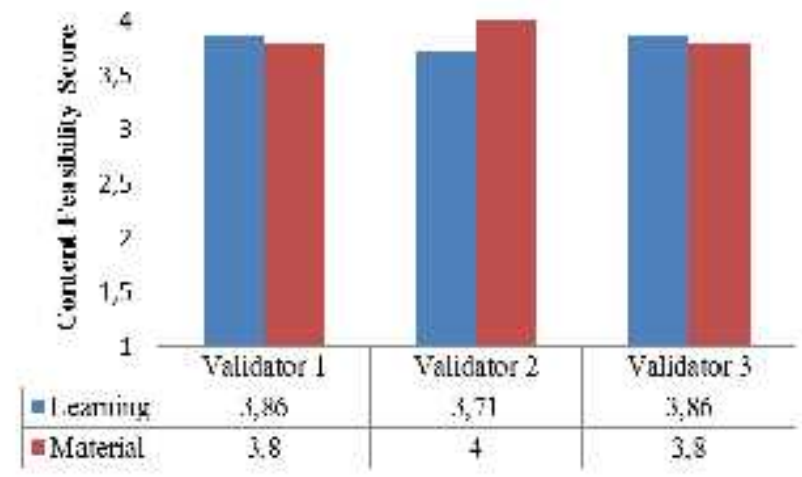

Fig. 2. Validation Results for Content Feasibility

\section{Language Feasibility}

Assessment of ICT based lectora inspire media on buffer solution by experts on the aspect of language feasibility was 3.78 in the valid category and could be used in the process of learning chemistry on buffer solution. Language feasibility of the contents could be seen in Fig. 3. 


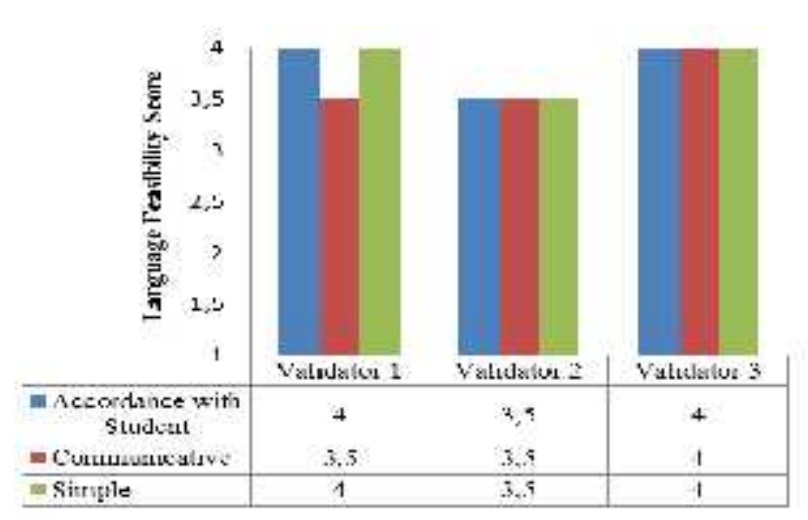

Fig. 3. Validation Results for Language Feasibility

\section{Presentation Feasibility}

Assessment of ICT based lectora inspire media on buffer solution by experts on the feasibility aspect of presentation was 3.73 in the valid category and can be used in the chemistry learning process in buffer solution. Presentation feasibility of the contents could be seen in Fig. 4.

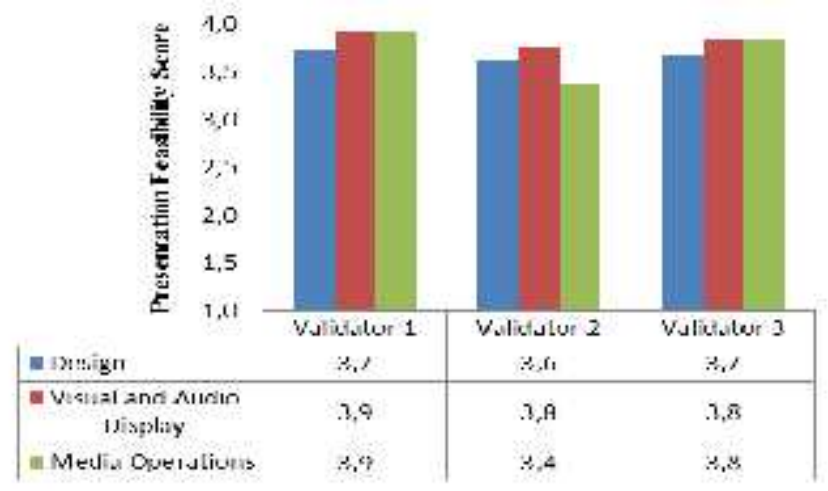

Fig. 4. Validation Results of Presentation Feasibility

\section{DISCUSSION}

The development of ICT-based lectora inspire media was carried out with a modified Borg and Gall development model. The results of the modification were divided into several stages. The first stage was needs analysis, media development and product assessment. The analysis phase needs researchers to conduct a literature study and a preliminary study. Literature study was done by reading research and literature. Based on the results of literature studies shows that learning media related to technology could help and facilitate the learning process.

The preliminary study begins by conducting interviews with chemistry teachers and students. The study aims to determine the field conditions at senior high school 1 Secanggang. Based on the results of interviews with teachers and students, it shows that teaching and learning process was still one way and teacher centered. Chemistry subject teachers still use the blackboard as a media for learning. This results in students 'teaching and learning process becoming less attractive and students found it was difficult to follow the learning process that could affect students' understanding and learning outcomes. Not yet available interesting learning media in the process of learning chemistry material buffer solution. Learning media that were used based on the results of interviews in the teaching and learning process have not varied and have not utilized technology that has developed. Students have a little difficulty in understanding the chemistry taught because there were no interesting learning media available. Most students need new learning media by using smartphone / android enhancements that could be used indefinitely by time and place.

Regarding information and communication technology, there were no restrictions on the use of smartphones by students in the school environment. In addition, the provision of computers was still limited and not sufficient for all students. Based on the results of the needs analysis, it could be concluded that senior high school 1 Secanggang requires a chemical learning media that was integrated with technology, information and communication. Media that was integrated with new enhancements and utilizes developing technology. As well as having an attractive appearance and easy to use without being limited in time and right. Thus, chemical media integrated with information and communication technology could help students in the learning process.

The next stage in the research process was the stage of media development. Chemistry learning media developed using lectora inspire software. Development begins with making a flowchart and storyboard. This aims to give researchers an overview of the learning media developed so as to facilitate the user in the operation process. The collection of learning media supporting materials such as pictures, videos, backgrounds, colors and other materials related to the buffer solution is carried out at this stage. The components of chemical learning media developed were, (1) the instruction menu contains initial instructions for the use of media and an explanation of the function of buttons and icons on the learning media, (2) the competency menu contains core competencies and basic competencies, (3) the material menu contains material buffer solution, (4) games menu contains buffer solution questions packed into four games, (5) evaluation menu contains buffer solution questions to be able to assess student learning outcomes at the end of the learning process, (6) profile menu contains data from media developer lectora inspire ICT based, (7) Videos on media, (8) Pictures on media (9) Animation on media.

The third stage was the stage of media assessment. Media assessments were carried out by expert validators namely material experts, educators and media experts. Product validation uses a questionnaire in accordance with the National Education Standards Board (BSNP). The feasibility aspects of the chemistry learning media developed based on the National Education Standards Board (BSNP) which have been modified include aspects of content feasibility, language feasibility, and presentation feasibility. In the aspect of content feasibility, there are two assessment components, namely learning and material. Expert validators gave an average value 
of 3.81 and 3.87. Therefore obtained an average content feasibility of 3.83. In the aspect of language worthiness there were three components of assessment; which were in accordance with student development, communicative and straightforward. Expert validators gave an average value of 3.83, 3.67 and 3.83. Therefore an average content worth of 3.77 is obtained. In the aspect of presentation feasibility, there were three components of assessment, namely design, audio and visual appearance and media operation. Expert validators gave an average value of $3.83,3.73$ and 3.71. Therefore obtained an average content worth of 3.73. Some of the findings during the use of lectora inspire assisted learning were that while using lectora inspire assisted learning students looked more enthusiastic, happy, excited, and active. This is in line with Linda et all that lectora based learning media inspire the subject of Salt Hydrolysis and Reaction Rate is valid and can be used as a learning media [12]. From the overall results of this study indicate that lectora inspire assisted learning can prove to be an alternative in buffer solution.

\section{CONCLUSION}

Based on the results of research and discussion, it could be concluded that the development of ICT based lectora inspire learning media has been carried out on the buffer solution with the Borg and Gall development model. And, the level of feasibility of ICT based lectora inspire learning media in accordance with the national education standards board (BSNP) is 3.77 with valid criteria.

\section{ACKNOWLEDGMENT}

Thank you to the Head of the Chemistry Study Program in Medan State University, Advisor I and Advisor II for the help, guidance, and direction given so that this scientific article could be resolved properly.

\section{REFERENCES}

[1]. L.N. Boyce, J. Van Tassel Baska, J.D Burruss, B.T Sher and D.T Johnson,"Aproblem-based curriculum: Parallel learning opportunities for students and teachers," Journal of the Education of the Gifted vol. 20, pp. 363-379, 1997

[2]. W. Saputra and B.E Purnama, "Pengembangan Multimedia Pembelajaran Interaktif untuk Mata Kuliah Organisasi Computer," Speed-Sentra Penelitian Engineering dan Edukasi, vol, 4(2), 2015.

[3]. A. Arsyad. Media Pembelajaran, Cet. I. Jakarta, PT. Raja Grafindo Persada, 1997.

[4]. A. Velázquez Marcano, V.M Williamson, G. Ashkenazi, R. Tasker and K.C Williamson, "The Use of Video Demonstrations and Particulate Animation in General Chemistry," Journal of Science Education and Technology, vol. 13(3), pp. 315-323, 2004.

[5]. L.B Munthe and M. Situmorang, "Pengembangan Media Pembelajaran untuk Meningkatkan Hasil Belajar pada Pengajaran Radioisotop," SEMIRATA, 2015

[6]. R. Toplis, "Probling student Teacher's Subject Content Knowledge in Chemistry: Case Studies Using Dynamic Computer Models," Chemistry Education Research and Practice, vol. 9, pp. 11-17, 2008.

[7]. M. Mas'Ud. Membuat multimedia pembelajaran dengan Lectora. Yogyakarta, Pustaka Shonif, 2014.

[8]. J. Varghese, M. Faith and M. Jacob, "Impact of e-resources on Learning in Biochemistry: First-Year Medical Students Perceptions," BMC Medical Education, vol. 12, pp. 21-29, 2012.

[9]. J.E Kemp and D.K Dayton, "Planning and producing instructional media," New York, Harper and Row Publisher, 1985.

[10]. A. Romadhan and P.W Rusimamto, "Pengembangan Media Pembelajaran Menggunakan Multimedia Interaktif Lectora Inspire Pada Mata Pelajaran Teknik Elektronika Dasar Di SMK Negeri 3 Jombang," Jurnal Pendidikan Teknik elektro, vol. 4(2), 2015.

[11]. W. Fajrina, M. Simorangkir and Nurfajriani, "Developing Interactive Computer Based Learning Media of Lectora Inspire to Enhance Conceptual Skills of Senior High Schools Students," Advances in Social Science, Education and Humanities Research, vol. 200. AISTEEL, 2018

[12]. R. Linda, E. Erviyenni, A.N Noer, N. Oktavianti and N. Sellyna, "Development of Lectora Inspire as Interactive Multimedia Chemistry Learning in Senior High School," Jurnal Pendidikan Kimia, vol. 8(3), 188-196, 2016 